\title{
doi.org/10.46291/ISPECIJSSHvol4iss3pp167-182
}

\section{Competitiveness of Turkey in Organic Olive and Olive Oil Sector}

\author{
Tuğçe KILIÇ \\ Ph.D. Student, Bursa Uludağ University, \\ Department of Agricultural Economics, \\ klctugce1@gmail.com, ORCID: 0000-0001-5886-8230
}

\section{Şule TURHAN}

Corresponding Author: Assoc. Prof. Dr. Bursa Uludağ University,

Department of Agricultural Economics, sbudak@uludag.edu.tr ORCID: 0000-0001-9155-8170

\begin{abstract}
Along with the growing interest in healthy living and nutrition in the world, the importance of production and consumption of wild olive and olive oil has been increasing in recent years. The competitiveness of industry in Turkey, not only to olive production, interest in the processing industry and commerce has boosted. Investments in olive and olive oil sectors from different sectors have increased. Starting from this approach, which is located in Turkey's two major export products of olive and olive oil sector has been the subject of this study. Comparative Export Performance (CEP) index was used to measure the competitiveness of the sector. The study covers the years 2005-2017. According to the findings obtained with the CEP index, it is seen that we do not have a competitive advantage in the olive oil sector and we have a competitive advantage in the olive sector against Egypt and Argentina. However, it has been determined that we do not have the same advantage against Spain, Greece and Morocco. Despite these results are included in Turkey's exports in the first two products in 10 countries.
\end{abstract}

Key words: Export Performance (CEP) Index, Olive, Organic, Olive Oil 


\section{Introduction}

In the 20th century, especially in the agricultural field, the fact that the public included a significant amount of scientific research has created agricultural yields and crop increases in industrialized countries. However, the negative changes in food products over time and the studies that reveal this have changed the outlook and expectation of agricultural production all over the world. Even at the expense of paying more to consume more natural and healthier foods, especially developed and rich countries have started to demand these quality agricultural products. Thus, organic farming started to be adopted in many countries (Merdan ve Kaya, 2013).

Today, the development of sensitivity towards healthy and natural nutrition and the prevalence of preferences for organic products increase the interest in organic olives and olive oil day by day. Especially in recent years, with the support of public institutions, olive trees are distributed to producers by demanding a free or very low fee. In addition, the producer is provided with direct income support for olive growing. Natural olive oils obtained from organic olives in the world attract a lot of attention. The natural processing of these products and their usefulness for health increase the interest. (Bojnec 2009, Donat 2017, Öztürk et all. 2010)

An increase in the ability and capacity of a country to produce indicates the competitiveness of that country (Akgüngör et all 2002, Bashimov 2017). By measuring the economic performance of a company or country, it is possible to make comparisons about both national and international competitive status (Şahinli 2014). This study aims to evaluate the general economic outlook and country's economy, as organic olive farming, which has an important potential, is developing rapidly in the world and in our country. In the first part of the study, the current situation of organic olives and olive oil in our country has been tried to be determined. In the second part of Comparative Export Performance (CEP) Turkey's competitiveness in the face of the most powerful countries in the sector it was examined using the index. In the last part, the results are discussed, suggestions are made and assumptions and suggestions are made regarding the export of organic olive products. 


\subsection{Organic Olive Production in the World}

According to the world organic agriculture report, in 2017, surveys were conducted considering 181 countries. It is stated that the agricultural lands used for olive cultivation increase regularly every year. Not only organic agricultural lands have increased all over the world, but organic product markets have increased in parallel with the increase in the number of organic producers. According to the report, approximately 890,000 hectares (20\%) of the total organic farming areas were used for olive cultivation in 2017. According to 2004 data, organic olive farming areas, which are 315,000 hectares, have increased approximately three times in the last period (Figure 1). In 2017, the share of organic olive fields was specified as $8.3 \%$ of olive groves in the world. On the other hand, with olive, dried legumes and vegetables, it has increased production over $15 \%$ compared to the previous year and entered the category of permanent products (https://www.oliveoiltimes.com).

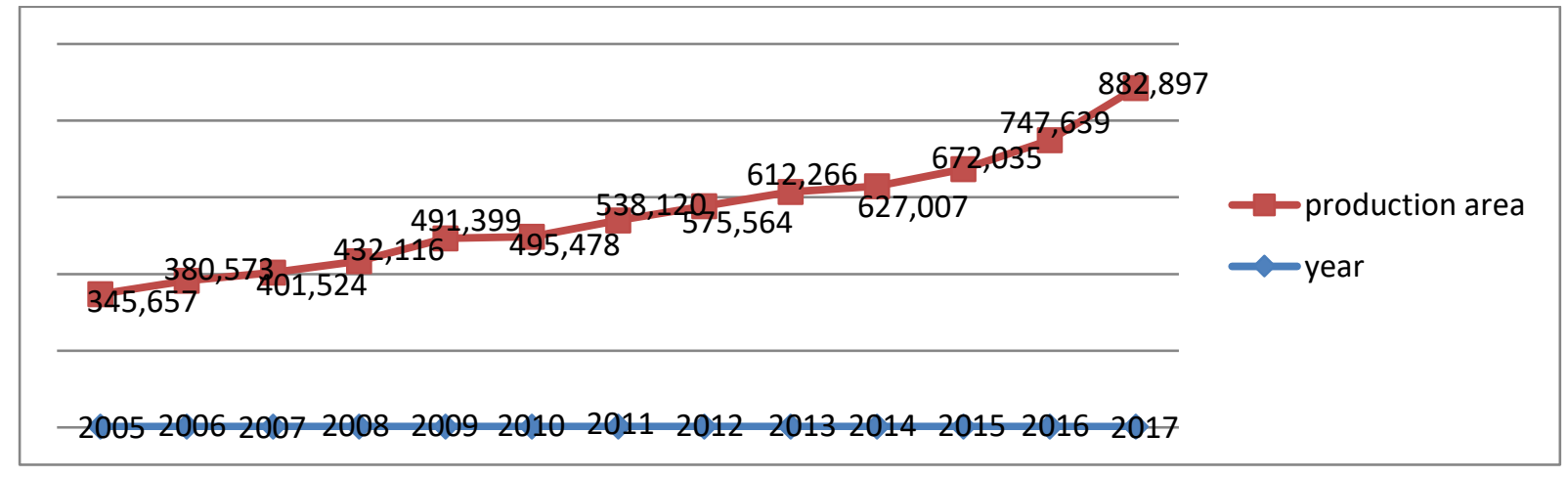

Figure 1. Total organic olive production areas in the world (2005-2017)

Source: FIBL,2017

Looking at the geographical data in detail, $70 \%$ of the organic olive groves in the world are in Europe and $30 \%$ are in North Africa. As shown in Figure 2, Tunisia is a North African country that hosts approximately $99 \%$ of organic olive fields. It is the country with the largest organic land area devoted to olive cultivation with more than 250.000 hectares. That 235,000 hectares why Italy, Spain 195.000, 82.000 Turkey and the fifth one is to follow Greece it takes 50,000 hectares (FIBL 2017). 


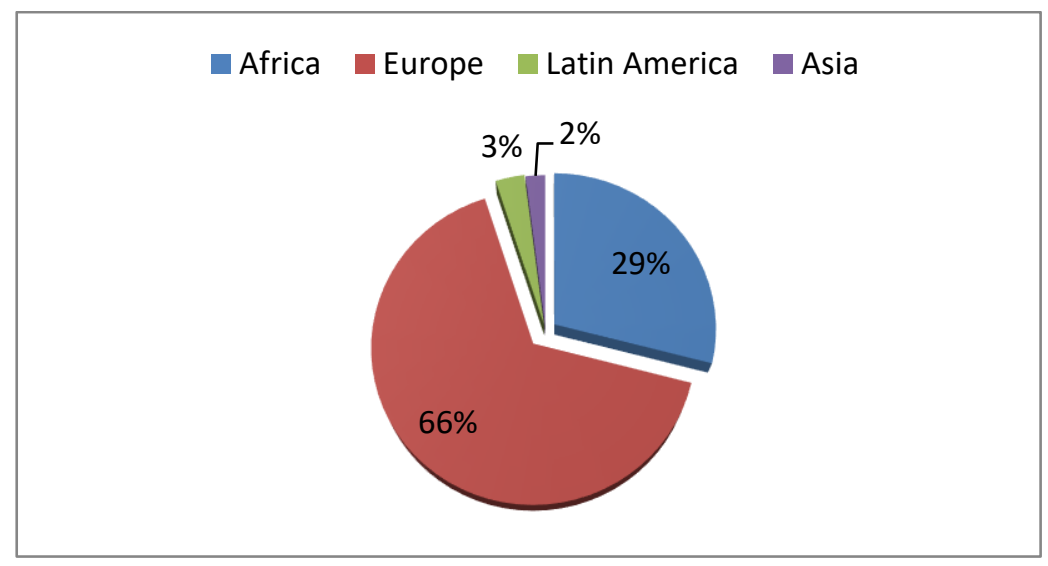

Figure 2. Countries where organic olive fields are most concentrated (2017)

Source: FIBL,2017

In Figure 3, the shares allocated for organic cultivation within the total olive fields are shown on the basis of countries. Accordingly, $8 \%$ of the total olive gardens of Spain, which is the world's largest traditional olive producer, is only organic, while the share of Tunisia in the total land is reported as $15 \%$. When we examine France, which is one of the smaller producers of olive farming, it is seen that the share of organic olive groves in the total olive groves is $27.3 \%$. Following France, Slovenia with the highest share of organic olives has 20\%, Italy and Cyprus with 17\%, and fifth with 14.6\% after Tunisia (FIBL 2017).

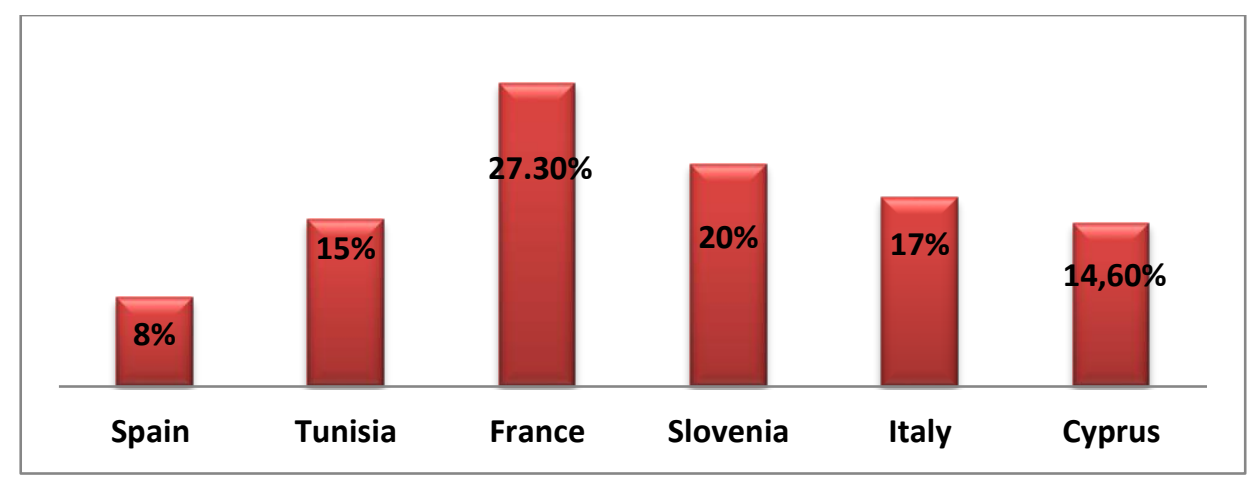

Figure 3. Share of organic olive fields in total olive fields (2017)

Source: FIBL,2017, FAO 2017.

According to 2017 data of FAO and Eurostat, there was a parallelism between organic olive production quantities and production areas. It is shown in Figure 4 that Tunisia is the country with the most organic olive production area in North Africa. It has become the country with the highest production volume with its production of approximately 1 million tons. followed by Tunisia with 942964 tonnes in Italy, 780456 tons by Spain, Greece and Turkey came to 332344 tons and 200340 tons in production represent the top 5 countries. When the countries are analyzed in detail, it is noteworthy that France is the country with the largest share in Year 4/ 2020, Volume-4, Issue-3 | wwW.ispecjournal.org 
organic production in total olive fields, but it remains lower in production. Its location and climate characteristics necessitated the production to be limited only to the Mediterranean part. (Figure 4).

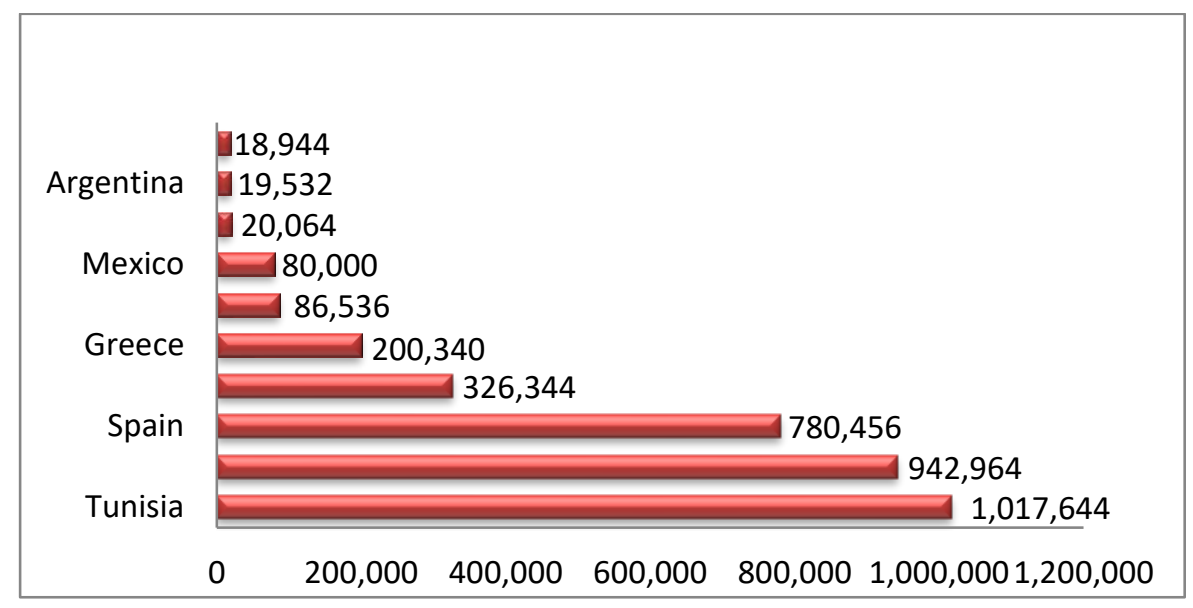

Figure 4. Organic olive production in the world (2017)

Source: FIBL,2017

In Europe, there has been a $92 \%$ increase in organic olive cultivation in the last 10 years. 11\% (592 $600 \mathrm{ha}$ ) of the total olive fields are the areas where organic olive cultivation is done. The African continent, almost all of which is located in Tunisia, follows Europe with an area of 257,000 ha. Latin America uses 25,500 hectares organically. Organic olive groves in Asia cover 16,500 hectares and North America, which has less area, is 1800 hectares. (Figure 5). In addition, agricultural lands devoted to organic olive growing continue to grow globally. Looking at 2017, an $8.3 \%$ increase was observed compared to the previous year and this situation continues to increase due to $18 \%$ of the organic lands used for olive groves are in conversion and progressing towards being completely organic (https://www.organicworld.net)..

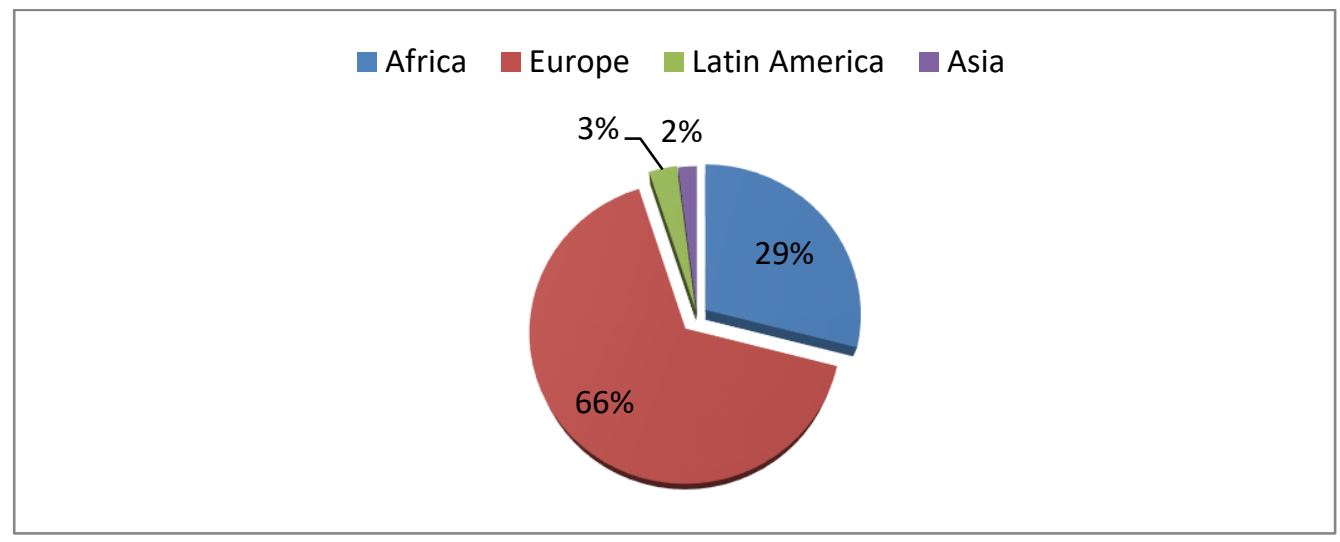

Figure 5. The share of organic olive fields to the continents (2017); Source: FIBL,2017 


\subsection{Organic olive production in Turkey}

With the expansion of a balanced and healthy diet conscious world, Turkey also expanding rapidly since the mid-1990s, organic farming and organic olive cultivation accordingly, a concept that has been gaining importance. The olive and olive oil production through organic farming practices have earned it a new dimension and compliance requirements of Turkey's geography, lack of excessive chemical drug usage habits in both olive producers control methods has led to certain areas of concentration of the organic oilseed and table olive production (Köksal 2019). Organic olive fields in Turkey, total organic olive area (converted and down-conversion) and their share in the total area is shown in Table 1.

Table 1. Organic olive fields and shares in the total area in Turkey

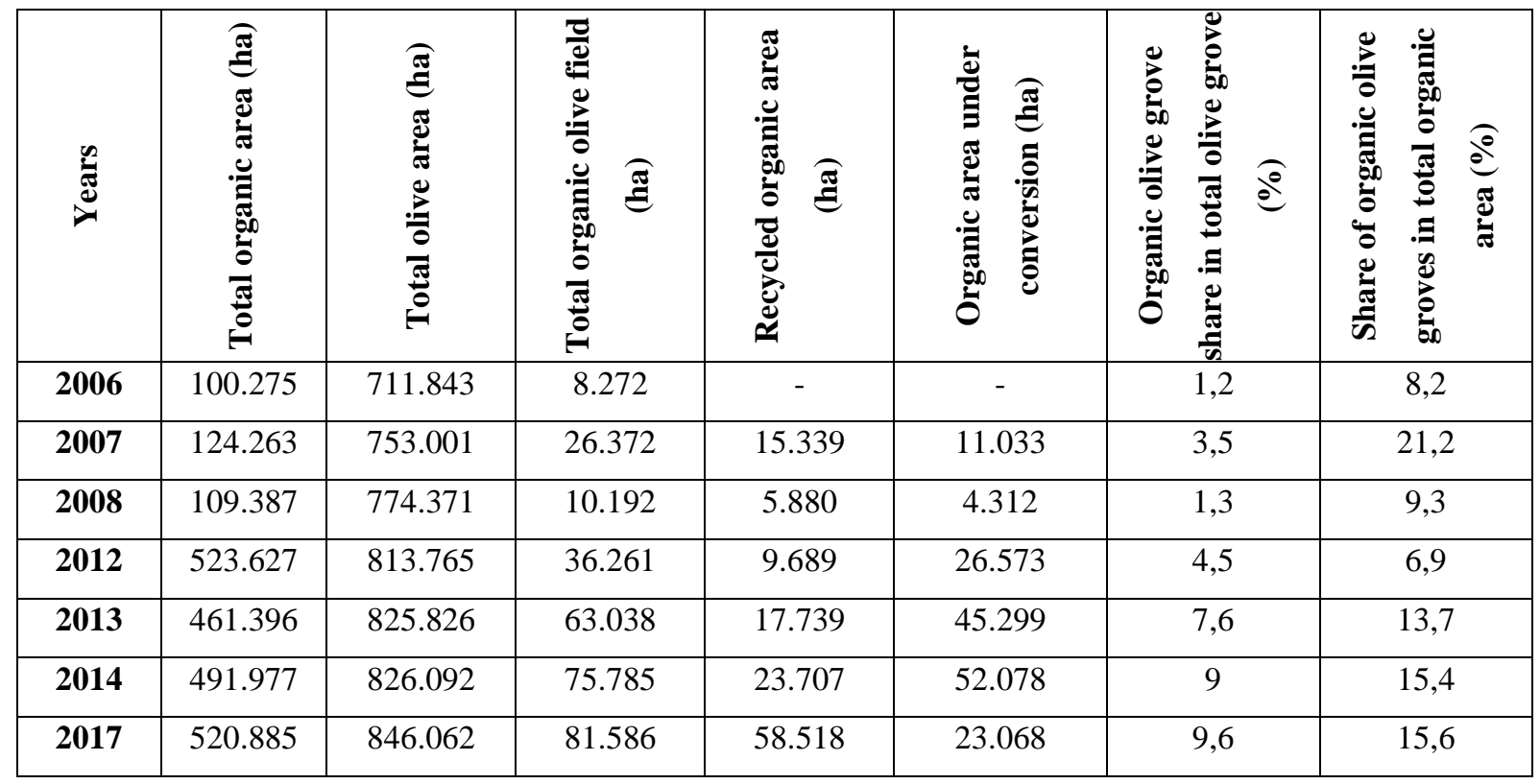

Source: FAO 2017, FIBL 2017

The increase in organic olive fields over the years shows an increase similar to organic production areas. In 2017, organic olive field increased by 10 times compared to 2006 and became 81,586 hectares. Among the total organic areas, the ratio, which was $8.2 \%$ in 2006 , increased in 2017 and reached $15.6 \%$. Similarly, while the share of organic olive fields in total olive groves was $1.2 \%$ in 2006 , this rate increased to $9.6 \%$ in 2017 . When we look at organic olive production in our country, a total of 19795 tons were produced in 2006, including the transition period. By 2017, this figure increased to 332,473 tons. It is shown in 
Table 2 that there is no steady increase in production between years and fluctuations occur in production. One of the reasons for these increases and decreases in production is that olive is one of the products most affected by climate changes. Adverse weather conditions including drought in particular is causing the fluctuation of production in producing countries such as Turkey.

Table 2. Total organic olive production in Turkey

\begin{tabular}{|c|c|c|c|}
\hline \multirow{2}{*}{ Years } & Transition Period & Organic Production Period & $\begin{array}{c}\text { Total } \\
\text { Production } \\
\text { (ton) }\end{array}$ \\
\cline { 2 - 4 } & $\begin{array}{c}\text { Amount of Organic Olive } \\
\text { Produced (ton) }\end{array}$ & Organic Olive Production (ton) & 19795 \\
\hline $\mathbf{2 0 0 6}$ & 6680 & 13115 & 17662 \\
\hline $\mathbf{2 0 0 8}$ & 5569 & 12093 & 28206 \\
\hline $\mathbf{2 0 0 9}$ & 6630 & 21576 & 32977 \\
\hline $\mathbf{2 0 1 0}$ & 15130 & 17847 & 33559 \\
\hline $\mathbf{2 0 1 1}$ & 15726 & 17833 & 112188 \\
\hline $\mathbf{2 0 1 2}$ & 69604 & 42584 & 99152 \\
\hline $\mathbf{2 0 1 3}$ & 69795 & 29357 & 142516 \\
\hline $\mathbf{2 0 1 4}$ & 99185 & 43331 & 164291 \\
\hline $\mathbf{2 0 1 5}$ & 101629 & 62662 & 221504 \\
\hline $\mathbf{2 0 1 6}$ & 128131 & 93373 & 261978 \\
\hline $\mathbf{2 0 1 7}$ & 93633 & 168345 & 332473 \\
\hline $\mathbf{5 y y n}$ & 102948 & 229525 & \\
\hline
\end{tabular}

Source: Ministry of Agriculture and Forestry, 2018.

When the distribution of organic olive fields examined in 2006 by province Muğla has $43 \%$ of the total organic olive fields in Turkey. Between 2009 and 2017, Aydin has an important place in production. Especially when we look at 2017, Aydin has the most organic olive production with 53\% and Mersin follows Aydın with 18\%. Considering the years of 20092017, Aydın, İzmir and Manisa are among the most important provinces in organic olive cultivation by meeting nearly $70 \%$ of the production (Table 3 ). 
Table 3. Organic olive production by province in Turkey (ton)

\begin{tabular}{|c|c|c|c|c|c|c|c|c|c|c|}
\hline Provinces & $\mathbf{2 0 0 6}$ & $\mathbf{\%}$ & $\mathbf{2 0 0 9}$ & $\mathbf{\%}$ & $\mathbf{2 0 1 2}$ & $\mathbf{\%}$ & $\mathbf{2 0 1 5}$ & $\mathbf{\%}$ & $\mathbf{2 0 1 7}$ & \% \\
\hline Aydın & 2346 & 13,5 & 9526 & 29,1 & 57574 & 56,7 & 79448 & 50 & 200001 & 53,4 \\
\hline İzmir & 355 & 2,0 & 8821 & 26,9 & 14612 & 14,4 & 22390 & 14,1 & 19671 & 5,2 \\
\hline Manisa & 808 & 4,6 & 2945 & 9,0 & 12009 & 11,8 & 28375 & 17,8 & 26705 & 7,1 \\
\hline Mersin & 1025 & 5,9 & 947 & 2,9 & 1844 & 1,8 & 2709 & 1,7 & 69900 & 18,4 \\
\hline Çanakkale & 2833 & 16,3 & 2101 & 6,4 & 5504 & 5,4 & 5973 & 3,7 & 6728 & 1,7 \\
\hline Muğla & 7507 & 43,1 & 557 & 1,7 & 1844 & 1,8 & 950 & 0,6 & 11959 & 3,2 \\
\hline Kilis & - & - & 1272 & 3,9 & 1758 & 1,7 & 8461 & 5,3 & 13273 & 3,5 \\
\hline Hatay & 1958 & 11,2 & 5493 & 16,8 & 1718 & 1,7 & 2890 & 1,8 & 8038 & 2,1 \\
\hline Gaziantep & - & - & 208 & 0,6 & 2865 & 2,8 & 2797 & 1,8 & 11132 & 3,0 \\
\hline Balıkesir & 400 & 2,3 & - & - & 28 & 0,03 & 1806 & 1,1 & 2114 & 0,6 \\
\hline Adıyaman & - & - & 10 & 0,06 & 832 & 0,8 & 879 & 0,6 & 2923 & 0,8 \\
\hline Denizli & 157 & 0,9 & 609 & 1,8 & 201 & 0,2 & 788 & 0,5 & 846 & 0,2 \\
\hline Şanlıurfa & - & - & 116 & 0,3 & 243 & 0,2 & 793 & 0,5 & 585 & 0,1 \\
\hline Adana & 10 & 0,1 & 14,3 & 0,04 & 362 & 0,3 & 678 & 0,4 & 753 & 0,2 \\
\hline Bursa & - & - & 98 & 0,4 & 55 & 0,05 & 48 & 0,03 & 153 & 0,04 \\
\hline Antalya & - & - & 24,5 & 0,07 & 31,3 & 0,03 & 33 & 0,02 & - & - \\
\hline Total & $\mathbf{1 7 3 9 9}$ & $\mathbf{1 0 0}$ & $\mathbf{3 2 7 4 2}$ & $\mathbf{1 0 0}$ & $\mathbf{1 0 1 5 2 5}$ & $\mathbf{1 0 0}$ & $\mathbf{1 5 9 0 1 8}$ & $\mathbf{1 0 0}$ & $\mathbf{3 7 4 8 0 6}$ & $\mathbf{1 0 0}$ \\
\hline
\end{tabular}

Source: Tarım ve Orman Bakanlığı, 2018

In 2006, Turkey made a total of 38 tons of organic table olive exports and revenue of $\$ 103$ 810 was obtained. According to the data of the Ministry of Agriculture and Forestry, 2015 is the latest in the export of olives and olive products. Accordingly, it was recorded that 26.562 dollars of income was obtained from the export of 2.3 tons of table olives (Table 4). In 2013, 37,547 tons of organic olives and products were exported and 233,368 dollars were earned. In 2018, 707 tons of exports were made, but no revenue was specified. There is no import data in organic olives and products in our country. Only 1000 liters of olive oil imported from Italy in 2018 are included in the system of the Ministry of Agriculture and Forestry.

Table 4. Turkey's total exports of organic olives

\begin{tabular}{|c|c|c|c|c|c|c|}
\hline \multirow{2}{*}{ Years } & \multicolumn{7}{|c|}{ Export (ton) } \\
\cline { 2 - 7 } & Table Olive & $\mathbf{\%}$ & $\mathbf{( \$ )}$ & Oil & \% & (\$) \\
\hline $\mathbf{2 0 0 6}$ & 38 & 100 & 108407 & - & - & 103810 \\
\hline $\mathbf{2 0 0 7}$ & 56 & 80 & 115527 & 14 & 20 & 102047 \\
\hline
\end{tabular}




\begin{tabular}{|c|c|c|c|c|c|c|}
\hline $\mathbf{2 0 0 8}$ & 54 & 79 & 201487 & 14 & 21 & 107026 \\
\hline $\mathbf{2 0 0 9}$ & 1,2 & 4 & 6111 & 34 & 96 & 211911 \\
\hline $\mathbf{2 0 1 0}$ & 8 & 94 & 19032 & 0,5 & 6 & 13574 \\
\hline $\mathbf{2 0 1 2}$ & - & - & - & 7,8 & 100 & 44087 \\
\hline $\mathbf{2 0 1 5}$ & 2,3 & 100 & 26562 & - & - & - \\
\hline
\end{tabular}

Source: Ministry of Agriculture and Forestry, 2018

Turkey serves organic olive products and export more than 92 tonnes at Germany. 49 tons of it is exported as table and 43 tons are exported as olive oil. Following Germany, 48 tons of table olives and about 21 tons of olive oil in total are 69 tons of organic olives and the country is exported to the United StatesThe countries that follow these two countries in the export of organic table olives are Greece, Canada, Netherlands, Sweden and other countries, respectively. Canada, United Arab Emirates, Malaysia, Japan and other countries are included in olive oil exports (Ministry of Agriculture and Forestry, 2018).

\section{Material Method}

\subsection{Material}

The research is based on secondary data. Turkey's organic olives and olive oil, the United Nations Food and Agriculture Organization (FAO), Turkey Statistical Institute (TUIK), the European Statistical Office (Eurostat), European Statistical Office (FIBL) and is provided from the Agriculture and Forestry Ministry data base. The research covers the period of 20052017. In addition, national and international studies and statistics on the subject of research have been used.

\subsection{Method}

The aim of this study was to assess the export performance of Turkey's olive oil and table olives in the product and show the level of development accordingly. Thus, depending on the findings so that policy recommendations can be put forward competitive advantage or disadvantage of Turkey in these products could be developed. The first study to measure the competitiveness of a country provided that it makes use of the export data was made by Liesner (1958), and the calculation of the index value used the ratio of the country's total exports to one product to the total exports of other countries exporting that product. (Utkulu and Seymen 2004). Donges et all. Comparative Export Performance (CEP), developed by 
(1982), is an index used to measure sectoral competitiveness of a country against rival countries, which is formed by the development of Balassa index. (Saraçoğlu and Köse 2000, Suntharalıngam et all. 2011, Torayeh 2013, Boansi 2014, Alidou et all. 2017).

Turkey's important place in the export of agricultural products is orange, tangerine, lemon and apricot product specialization level of competitiveness due to export performance was measured according to a comparative index (Kösekahyaoğlu and Özdemir, 2019). Kuşat did a study he did in 2019. In this study, application for full EU membership for Turkey, which reached nearly 60 years, the candidate countries against the comparative export performance has been calculated on the basis of selected sectors frame. For products subject to this study, measurement, Turkey and competitiveness on a global scale with five competing countries it was carried out by comparison. The findings were evaluated using the Comparative Export Performance (CEP) index reference criterion. The export data of the agricultural products whose comparative export performance is measured and the export data of the countries in which they are compared are calculated from the FAO database. The formula of the comparative export performance index is as shown below (Rana 1988, Bekmez and Tezioğlu 2008, Erkan 2012, Şahin 2016, Kuşat 2019)

$$
\mathrm{CEP}_{\mathrm{TRz}}=\left(\mathrm{X}_{\mathrm{tiz}} / \mathrm{X}_{\mathrm{rz}}\right) /\left(\sum \mathrm{X}_{\mathrm{it}} / \sum \mathrm{X}_{\mathrm{rt}}\right)
$$

$\mathrm{CEP}_{\mathrm{TRz}}=$ Turkey $(\mathrm{T}), \mathrm{R}$, refers to the comparison made competing countries. Accordingly, CEP, shows the comparative export performance index of the two countries.

$\mathrm{X}_{\mathrm{tiz}}=$ Turkey's export performance refers to the measured product exports.

$\mathrm{X}_{\mathrm{rz}}=\mathrm{It}$ refers to the export of the competitor country in comparison to the product in question.

$\sum \mathrm{X}_{\mathrm{it}}=$ It represents Turkey's total exports.

$\sum \mathrm{X}_{\mathrm{rt}}=$ Refers to the total exports of the competitor country compared.

If the index value is greater than 1 , this indicates that the country is advantageous in exports in that product group. If it is less than 0 , it shows that the country in question does not have an advantage in exports in that product group (Şahin, 2016).

Below are listed the SITC codes for the products whose level of specialization is measured in the study and the countries in which the products are compared in the analysis. 


\section{Organic Olive Oil}

Türkiye-İspanya, Turkey-Italy, Turkey-Portugal, Turkey-Greece, Turkey and Tunisia

\section{Organic Table Olives}

Turkey-Egypt,Turkey-Argentina, Turkey-Spain, Turkey-Greece, Turkey-Morocco

\section{Research Findings}

According to the data obtained, the CEP index was calculated for 2005-2017 by taking into consideration 5 countries with high competitive power in organic olive oil (Spain, Italy, Portugal, Greece and TunisiaValues calculated according to these countries are less than 0 , which is the reference criterion. These results show us that although we are among the top 6 countries in organic olive oil exports, we do not have a competitive advantage over the compared countries. Turkey's only a competitive advantage against Portugal in 2005. CEP results in index between Portugal and Turkey was observed as close to 1 as watch. In this case, Portugal has a competitive advantage in olive oil, but it is possible to say that this difference is not high compared to other countries.

In Table $6 \mathrm{CEP}_{\mathrm{TRz}}$ index is given in table olive production in Turkey according to countries.

Çizelge 6. CEP ${ }_{\mathrm{TRz}}$ Index Results of Table Olive Products in Turkey

\begin{tabular}{|c|c|c|c|c|c|}
\hline Years & TR- Egypt & TR- Argentina & TR- Spain & TR- Greece & TR- Morocco \\
\hline $\mathbf{2 0 0 5}$ & 2 & 11 & 0 & 0 & 0 \\
\hline $\mathbf{2 0 0 6}$ & 4 & 6 & 0 & 0 & 0 \\
\hline $\mathbf{2 0 0 7}$ & 5 & 16 & 0 & 0 & 0 \\
\hline $\mathbf{2 0 0 8}$ & 1 & 13 & 0 & 0 & 0 \\
\hline $\mathbf{2 0 0 9}$ & 1 & 8 & 0 & 0 & 0 \\
\hline $\mathbf{2 0 1 0}$ & 2 & 8 & 0 & 0 & 0 \\
\hline $\mathbf{2 0 1 1}$ & 1 & 10 & 0 & 0 & 0 \\
\hline $\mathbf{2 0 1 2}$ & 1 & 10 & 0 & 0 & 0 \\
\hline $\mathbf{2 0 1 3}$ & 1 & 7 & 0 & 0 & 0 \\
\hline $\mathbf{2 0 1 4}$ & 1 & 11 & 0 & 0 & 0 \\
\hline $\mathbf{2 0 1 5}$ & 1 & 11 & 0 & 0 & 0 \\
\hline $\mathbf{2 0 1 6}$ & 0 & 6 & 0 & 0 & 0 \\
\hline $\mathbf{2 0 1 7}$ & 0 & 7 & & 0 & 0 \\
\hline
\end{tabular}


Table 6 shows that when evaluating Turkey's competitive advantage across Egypt and Argentina. But it does not have the same advantage against Spain, Greece and Morocco.

\section{Result}

Our country is among the countries that have an important place in olive oil and table olive exports. At the same time, as stated in the first part of the study, we see that these products have the same importance in their organic production in our country. Eight countries, which we have evaluated, are among the leading countries in the world, as in organic olive and olive oil production, conventional production and export. On the other hand, while there is a database of countries' organic olive and olive oil productions, the desired data regarding the export amounts could not be reached by years. Therefore, Turkey's starting organic olives and olive oil production is an important place to give direction to the organic production and exports, strong and objective of this study is to determine the weaknesses of our country. Taking into consideration the data available, the CEP index was calculated. When the MODE index of table olives result shows that Turkey's export performance was strong compared to Egypt and Argentina. However, it does not have the same advantage against Spain, Greece and Morocco.

Most of the table olive farms could not reach the desired level in both domestic and foreign markets. Also, it could not produce a standard production. This is due to the fact that it consists of small family businesses and therefore the lack of adequate technical and hygienic infrastructure. Few but modern table olives have difficulties in providing quality inputs required for a standard and sustainable production. This affects directly processed table olive production. In order not to increase the problems experienced in table olives marketing, it is recommended to go out of certain varieties and make necessary $R \& D$ studies on the saplings. The existence of some companies related to this is a positive development in terms of increase in production, quality and sustainability (Özkaya et all. 2010). When we evaluate this study over organic table olives, similar problems are encountered. The aim of this study is to strengthen the export performance of our country, and to compete with countries that have leadership in organic olives such as Spain, Greece and Morocco. Our being among the leading countries in the production of organic table olives shows that we can have a voice in the international market. However, both the inadequacy of R\&D studies and the mistakes made after production, processing and harvesting also pose a problem in not reaching the desired 
level in exports. For this reason, giving the necessary sensitivity to marketing activities and R\&D activities is important in terms of strengthening the production and export of organic olives.

When we look at the CEP Olive index results compared across countries shows that Turkey's lack of competitive advantage. One of the reasons for this is that winter cold is effective in our country and it limits production. Otherwise, it is a product that can be grown all over Anatolia. Currently, olive cultivation is carried out in 41 provinces. Turkey's largest oil market in the EU, our country has been implementing a special customs duty based on the quality of the origin of olive oils. Within the scope of the Association Council Decision, 10\% customs tax deduction is applied for crude oils and 5\% for other oils based on special customs taxes. Thus importing countries involved in the EU, Inward Processing Regime while pouring olive oil imports from Turkey for their scope, our country is not boxed high value-added export of olive oil. However, through bilateral agreements with Tunisia, Algeria, Morocco and Lebanon, the EU has provided important privileges in olive oil exports to these countries. Our country can also be duty-free export of olive oil to the EU and other countries of the rights granted to conduct the necessary studies to Turkey for recognition is important. Within the scope of the Association Council Decision, there should be attempts to further develop the concessions made by the EU to our country and to make concessions to other countries. (Özkaya et all. 2010).

Similar problems are encountered when we evaluate the study through organic olive oil exports. It is important for the development of our country's exports to organize policies to increase the current 100-ton customs duty-free quota that the EU has given to our country for organic olive oil. In addition, in order to get a share of the increasing demand for organic olive oil in the USA, the amount of support given to organic olive oil should be increased. As a result, Turkey's value added exports of organic olives and olive oil and branding must find a solution to the problem, the more packaged, boxed and the Turkish olive oil to be exported to show to the world. In order to do this, the necessary supports should be provided to the producer and cooperative should be acted in order to enter the market more strongly. 


\section{References}

Akgüngör S., Barbaros F., Kumral N., (2002). Competitiveness of the Turkish fruit and vegetable processing industry in the European Union Market, Russian \& East European Finance and Trade, 38 (3): 34-53.

Alidou, M., Ceylan R.F., Ilbasmıs E. (2017). Trade and Revealed Comparative Advantage Measures: A Case of Main Export Crops of Benin Republic, Journal of Kastamonu University Faculty of Economics and Administrative Sciences, 18(1), 382-397.

Bashimov G., (2017). Grape Production and Export Performance in Turkey, U. U. Journal of Faculty of Agriculture, 31(2), pp.57-68.

Bekmez, S., Terzioğlu M. (2008). Methods of Measuring Competition, Competitiveness and Competitiveness, Turkey and the European Union Competition Sectoral Analysis Editör: Selahattin Bekmez, Nobel p., Ankara.

Boansi, D. (2014). Comparative Performance of Agricultural Export Trade: During and PostAgricultural Diversification Project in Ghana, British Journal of Economics, Management \& Trade, 4, Say1 10, 1501-11.

https://doi.org/10.9734/BJEMT/2014/10715

Bojnec S, Fertö I, (2009). Agro-food trade competitiveness of Central European and Balkan Countries, Food Policy, 34 (5): 417-425.

https://doi.org/10.1016/j.foodpol.2009.01.003

Donat, I. 2017. Opportunity to Create Added Value and Branding in Olive Oil https://www.bloomberght.com/.

Donges, J.B., C. Krieger-Boden, R.J. Langhammer, K-W. Schatz, C.S. Thoroe (1982). The Second Enlargement of The European Community: Adjustment Requirements and Challenges for Policy Reform, Kieler Studien, No:171. Kiel

Erkan B., (2012). Revealed Comparative Export Performance of countries with comparative advantages Coefficient Determination: The Case of Turkey-Syria ZKU Journal of Social Sciences, 8 (15) pp.195-218.

FAO. (2017). http://faostat,fao.org.(20.05.2020)

FİBL. (2017). https://statistics.fibl.org/world.html (20.05.2020)

Kuşat N., (2019). Comparative Export Performance (CEP) Candidate Countries Turkey's AB28 by the Opposite Competitiveness Index (2006-2016), Hacettepe University Journal of Faculty of Economics and Administrative Sciences 37 (1) pp. 111-133. https://doi.org/10.17065/huniibf.364137

Year 4/ 2020, Volume-4, Issue-3 | www.ispecjournal.org 
Liesner, H.H. (1958).The European Common Market and British Industry",.Economic Journal, 68: 302-316. https://doi.org/10.2307/2227597

Merdan K., Vedat K., (2013) Economic Analysis of Organic Agriculture in TurkeyJournal of Atatürk University Institute of Social Sciences, 17 (3) pp.239-252.

Özdemir, M. B., Kösekahyaoğlu, L. (2019). Turkey's orange, mandarin, lemon and apricot age in Comparative Export Performance and Competitiveness Analysis Products.

International Refereed Journal (ASSAM-UHAD)-ASSAM International Refereed. 6(14), 84105.

Özkaya, M. T., Tunalığlu, R., Eken, Ş., Ulaş, M., Tan, M., Danac1, A., İnan, N., Tibet, Ü. (2010). Problems and Solutions of the olive Turkey. Chamber of Agricultural Engineers, gricultural Engineering VII. Technical Congress, 11-15 January, Ankara, 515-537.

Öztürk, F.Yalçın, M.Varol H. (2010). Economic Analysis Of Conventional And Organic Olive Cultivation in The Aegean Region. Turkey IV. Organic Agriculture Symposium, Erzurum, 28 June - 1 July 2010.

Rana, P. B., (1988). Shifting Revealed Comparative Advantage: Experiences of Asian and Pacific Developing Countries, Asian Development Bank, 42.

Saraçoğlu, B., Köse N. (2000). International Competitiveness of Some Food Industries: Pasta, Biscuit and Flour Industry, Project Report, 2000-2, May 2000, Ankara.

Suntharalıngam, C. Ruslı, R., AB Halim, N. (2011). Competitiveness of Malaysia's Fruits in the Global Agricultural and Selected Export Markets: Analyses of Revealed Comparative Advantage (RCA) and Comparative Export Performance (CEP), Economic and Technology Management Review, Vol. 6 (2011):1-17.

Şahin, D. (2016). Measurement of the Competitiveness of the Manufacturing Industry: The Case of Turkey and the BRIC Countries. Ege Acadeic Review. 16(4), 709-718. https://doi.org/10.21121/eab.2016.480

Şahinli, M.A. (2014). Revealed Comparative Advantage and Competitiveness: Turkey Agriculture Sector, Yüzüncü Y1l University Journal of Agricultural Sciences (YYU J AGR SCI) 2014, 24(3): 210- 217.

https://doi.org/10.29133/yyutbd.236276

T.R Ministry of Agriculture and Forestry (2017). Bitkisel Üretim, Organik Tarım İstatistikleri.

https://www.oliveoiltimes.com (20.05. 2019).

Year 4/ 2020, Volume-4, Issue-3 | www.ispecjournal.org 
https://doi.org/10.1055/s-0039-1692350

Torayeh, N.M. (2013) The Competitıveness Of The Egyptıan Agricultural Export in the EUF Market; Should Egypt Diversify Its Trade Pattern? Applied Econometrics and International Development 13(2).

Utkulu, U. Seymen D. (2004). Revealed Comparative Advantage and Competitiveness: Evidence for Turkey vis-a-vis the EU/15. Paper Presented on the European Trade Study Group 6th Annual Conference ETSG, Nottingham. 